УДК 334.78

DOI: https://doi.org/10.37320/2415-3583/11.12

Дюк А.А.

кандидат економічних наук, доцент, Вінницький національний аграрний університет ORCID: https://orcid.org/0000-0001-6480-0558

\title{
СОЦІАЛЬНО-ЕКОНОМІЧНА РЕЗУЛЬТАТИВНІСТЬ ПІДПРИЕМНИЦЬКОГО ГОСПОДАРЮВАННЯ У РОЗВИТКУ СЕЛА: АСПЕКТ ЗАЙНЯТОСТІ
}

\begin{abstract}
У статті здійснено теоретико-практичні оцінки соиіально-економічної результативності підприємницького господарювання у розвитку села щзодо сучасних аспектів зайнятості населення та мотивацї праці. Обтрунтовано засади значущьості сільського підприємництва як механізму сприяння розвитку сільських територій - чинника, від якого вони фундаментально залежать. Визначено методичну сукупність оціночних секторів, у яких пропонується зафіксувати методичну сукупність показників для аналізу результатів діяльності підприємств, щчо мають сочіально-економічний зв'язок із розвитком села. Конщептуально запропоновані індикатори соціальноекономічної результативності підприємницького господарювання. Визначено системний зв'язок результативності підприємництва на селі з демографічними, соціальними, економічними та екологічними проблемами.
\end{abstract}

Ключові слова: підприємництво, господарювання, соціально-економічна результативність, зайнятість, мотивачія праці.

Постановка проблеми. Сільський сектор $є$ особливим господарським і життєвим середовищем соціально-економічних відносин. Його значущість як базової галузі для економіки України не потребує доведення. Проте ситуація в економіці глобальні, внутрідержавні, регіональні характеристики стану справ - кардинально змінилася. Наявна організаційно-економічна нестабільність, можливе поглиблення кризових явищ підтверджують необхідність наукового аналізу формування соціально-економічної результативності підприємницького господарювання у розвитку села.

Аेналіз останніх досліджень i публікацій. Проблема соціально-економічного розвитку села і сільських територій, також засади соціально-економічної результативності підприємницького господарювання, розроблена багатьма науковцями. Зокрема, дослідження національної моделі відносин у цій сфері здійснені у працях Ю. Лупенка [2; 3; 4; 12; 13; 17], М. Маліка [2; 13; $14 ; 17]$, В. Андрійчука [6], А. Сави [8], Б. Патона [9], Ю. Данько [10], П. Пашко [11], О. Шпикуляка [14], Н. Горіна [15], Е. Лібанової [16], 3. Варналія [18] та інших авторів [1-18]. Розробки спрямовані на оцінку науково-практичних засад, визначення особливостей соціально-економічного розвитку села, ефективності підприємницької діяльності в сільському господарстві. Загалом доведено, що сільськогосподарський, сільський сектор економіки України має специфічні особливості формування життєвого і господарського простору. Центральним елементом соціально-економічного життя у цій сфері завжди було, особливо в новітній період, і залишається село як сільське поселення та підприємство як виробничо-господарська структура. Навколо цих утворень акуму- люються ресурси, реалізовуються управлінські рішення щодо вирішення соціальних проблем сільського розвитку. Зі зміною парадигми державного управління відбулися організаційно-економічні перетворення в структурі сільськогосподарських формувань, що кардинально вплинуло на увесь процес сільського життя.

Виділення не вирішених раніше частин загальної проблеми. Проте соціально-економічні засади результативності функціонування підприємництва на селі потрібно розглядати у фокусі особливостей сільського розвитку. Їх доцільно різноаспектно оцінювати, зокрема відзначаємо важливість аналізу проблематики зайнятості i мотивації праці в аграрному підприємництві.

Мета статті - здійснення оцінки стану і значущостірезультативностіпідприємницькогогосподарювання у соціально-економічному розвитку села в аспекті зайнятості населення, мотивації праці.

Виклад основного матеріалу. Сільський сектор економіки, зокрема сільськогосподарська діяльність, характеризується особливою соціальною та економічною значущістю, а також результативністю. Сільськогосподарські підприємства, сільськогосподарські товаровиробники залучені як до господарської діяльності в аграрному виробництві, так і до процесів соціально-економічного забезпечення розвитку сільських територій. Ці суб'єкти виконують соціально-економічну роль як сектор зайнятості, створення додаткового продукту, здійснюючи функції охорони і збереження сільського навколишнього середовища тощо. Вони вбудовані в соціально-економічну модель життя і господарювання на селі як продуктивна сила, соціальні агенти, носії соціальної функції. Правильно вважається, що: «підприємництво є 


\section{Сектори формування характеристик результативності господарювання підприсмств у соціально-економічному розвитку села}

\begin{tabular}{|l|l|}
\hline Соціально-трудовий & Матеріального стимулювання \\
\hline
\end{tabular}

\section{Рисунок 1 - Оціночні сектори для аналізу ролі і соціально-економічної результативності підприсмницького господарювання у розвитку села * \\ Джерело: сформовано автором}

еволюційно зумовленою соціальною формою реалізації підприємливості індивідів, публічною діяльністю, спрямованою на досягнення ними власних цілей через задоволення (пряме чи опосередковане) потреб інших людей» [13]. Соціальноекономічний розвиток будь-якої системи, включаючи підприємства, характеризується наслідками функціонування, які втілюються у певних результатах. У тому числі це полягає у соціальній відповідальності: «Соціальна відповідальність суб'єктів підприємницької діяльності - це об'єктивна закономірність соціалізації сучасної економіки, яка свідчить про постійне вдосконалення форм і методів підприємництва і намагання його (підприємця) пристосуватися до складних умов господарювання у сучасному конкурентному середовищі» [18]. Відзначаємо соціальні й економічні результати господарювання підприємств, їхній безумовний зв' язок із розвитком сільських територій, що природно. Тому, ставлячи за мету вивчити особливу специфіку, оцінити тенденції і визначити значення соціально-економічної результативності функціонування підприємств у соціально-економічному розвитку села, сільських територій, слід звернути увагу на динаміку показників соціалізації бізнесу. При цьому аналіз здійснюватимемо, не відділяючи показники розвитку села і сільських (сільськогосподарських) підприємств. Слід врахувати аспект взаємозалежності тенденцій соціально-економічного розвитку села від результативності підприємницького господарювання. Це переконання відповідає оцінкам засад сільського розвитку, тому природним, соціальним, виробничим залежностям соціальних і економічних чинників. Також для представлення більш грунтовної доказової бази враховуємо методичну позицію про те, що: «Село - це тип поселення, жителі якого зайняті переважно у сільському господарстві. До сільських населених пунктів, за статистичним обліком, також належать станційні селища, шляхові дільниці, селища лісгоспів, зимівлі, інші дрібні селища, не пов'язані з сільським господарством» $[1$, c. 323]. Це визначення красномовно характеризує вибір пріоритетів у дослідженні піднятого у статті питання - зв'язку результативності господарювання підприємств і соціально-економічного розвитку села. Це стосується зайнятості та мотивації праці, формування добробуту сільських жителів - це показники, які перебувають у прямій залежності від ефективності функціонування суб' єктів господарювання.

Господарська діяльність підприємств за соціально-економічним критерієм результативності наведена на макрорівні (суб'єкт підприємництва), на макрорівні (соціально-економічна ситуація на селі), а також переноситься на мезорівень (кваліфікація поселень за рівнем адміністративнотериторіального устрою - регіональний вимір). 3 огляду на системну селозберігаючу значущість підприємств сільського сектору економіки обгрунтованою до використання вважаємо таку методичну сукупність показників у складі оціночних секторів (рис. 1):

1) соціально-трудовий - характеризує наявність і динаміку зайнятості населення;

2) матеріального стимулювання - характеризує політику підприємств у сфері формування мотивації праці через іiі оплату.

Соціально-економічну результативність господарювання вважаємо комплексним показником, який включає результати, утворені підприємствами. Вони спроектовані на діяльність підприємств і розвиток територіальних одиниць (наприклад, населений пункт, на території якого знаходиться підприємство), а також на зайнятих у виробництві. Це поняття кваліфікуємо як якість заходів і витрат, які впливають на забезпечення стандартів життя працівників підприємств та їніх сімей. Індикаторами соціально-економічних результатів вважаємо динаміку витрат на оплату праці, відрахування на соціальні заходи, розміру орендної плати за земельні і майнові паї. Відповідно, соціально-економічну результативність господарювання доцільно інтерпретувати як оціночний вияв соціальної відповідальності за критеріями аналізу діяльності сільськогосподарських підприємств. Ключовий фактор - співвідношення соціально-економічних вигод у здійсненні виробничо-господарської діяльності.

Соціально-економічний розвиток села характеризує фактичний рівень соціалізації економіки господарювання, тобто відношення підприємців до формування добробуту сільських територій. Це i $\epsilon$, на нашу думку, ефекти значущості результативності підприємницької діяльності в секторі 
виробництва сільськогосподарської продукції та продовольства зокрема. Розроблення питання соціально-економічної результативності господарювання як основи соціалізації підприємництва слід здійснювати з прив'язкою до розвитку сільської території. Адже сільськогосподарський бізнес і сільська територія, село у соціалізації результатів $є$ невіддільними одне від одного. Тим більше для України село - надзвичайно значуща сфера життєдіяльності людини, адже, за різними розрахунками, там проживають близько $30 \%$ наявного населення, а сільськогосподарський земельний фонд становить $70 \%$ від наявного в державі [2; $3 ; 4]$. Щодо сільських територій результативність господарювання визначає демографічні, соціальні, економічні та екологічні проблеми. Саме в межах їх вивчення й аналізу виникає методична доцільність розкриття тенденцій, результатів економічної соціалізації господарювання на селі.

Демографічні, депопуляційні проблеми поглиблюються, і ми також погоджуємося із думкою науковців Національного наукового центру «Інститут аграрної економіки», що «соціально-економічна криза в Україні зумовила несприятливі демографічні передумови відтворення сільського населення, тому погіршився демографічний потенціал, накопичений попередніми поколіннями. Станом на початок 2019 р. сільське населення України становило 12896,5 тис. осіб, що становить 30,6\% від загальної чисельності населення країни. За період з 1991 р. по 2018 р. чисельність сільського населення зменшилася на 4 млн осіб, або на $23,5 \%$, а кількість населених пунктів із чисельністю населення понад 500 осіб - відповідно на $9,6 \%$. Основною причиною кризи демографічного стану на селі $\epsilon$ активізація негативних процесів: з одного боку - зростання смертності, розлучень, старіння населення, 3 іншого - зменшення народжуваності та шлюбності селян» [2, с. 6]. Незважаючи на депопуляції, на наше переконання, розвиток виробничо-господарської сфери підприємств залишається вирішальною для зайнятості в сільському секторі. Ця закономірність очевидна, тому результативність господарювання, зокрема iii покращення, значиться серед пріоритетних завдань сьогодення, перспектив майбутнього. Адже теперішня ситуація в економіці і суспільстві формує ще більшу залежність від сільського сектору - це об' єктивно зумовлена проблема. До того ж галузі, яка володіє відновлюваними ресурсами, притаманна реальна спроможність стати ефективним сектором пом'якшення соціально-економічної кризи, що насувається.

Виходячи 3 реалій і традиційного сприйняття соціально-забезпечуючої ролі у розвитку територій, а також формуванні позитивної динаміки у національній економіці, значущість сільського господарства ще більше зросла. Особливо в умо- вах поглиблення економічної нестабільності, зростання безробіття і зниження доходів від сільськогосподарської праці. Проте для оцінки запасу галузевої міцності проведемо деякий ретроспективний аналіз результативності господарювання у соціально-економічному розвитку села. Методичні рамки такого аналізу відповідають таким аспектам, як: продуктивність і мотиваційна результативність у сільському господарстві; соціально-економічні показники розвитку сільськогосподарських підприємств; регіональні особливості розвитку підприємництва.

Переважно у дослідженнях підприємницьке господарювання розглядається як економічний чинник, проте його бажано поєднувати із соціальними аспектами. Тим самим соціально-економічна результативність комплексно характеризує динаміку ролі сільськогосподарського бізнесу у розвитку сільських територій.

Історично так склалося, що розвиток українського села, сільських територій предметно залежить від соціально-економічної результативності підприємств, які діють у секторах сільського, рибного та лісового господарства. Це природний зв'язок, адже ці галузі територіально розміщені на селі, автоматично стають потенційною сферою для зайнятості селян. Незважаючи на різні демотиваційні чинники, загальну непривабливість сільськогосподарської зайнятості в Україні, галузь залишається однією з основних у використанні робочої сили (табл. 1).

За період 2015-2019 рр. чисельність зайнятих у сільському, лісовому та рибному господарстві України становила близько 3 млн осіб (див. табл. 1). Відносна сталість кількості зайнятих підтвердження стабільності розвитку, результатів підприємницького господарювання, які мали місце донедавна. Зокрема, сільськогосподарська діяльність із природних причин акумулює відносно сталу чисельність робочої сили.

Також інколи на селі окрім сільського господарства немає інших сфер для найму на роботу. Тому з позицій зайнятості, соціально-економічну результативність підприємств на селі оцінюємо 3 урахуванням природного фактору за критеріями зайнятості й мотивації праці. Адже у разі цієї галузі аспект доцільності найму робочої сили, а також виробництва сільськогосподарської продукції діє не завжди. Питання в тому, що сільськогосподарська галузь вирішує ключові питання - продовольчої безпеки, забезпечення фактичної життєдіяльності людини. Нинішній фактичний стан за підсумками 2019 року щодо зайнятості може відрізнятися від поточного у 2020 році через негативний вплив пандемії, зміну структури виробництва тощо. Кількість працевлаштованого населення може зменшитися, бо у кризовій ситуації підприємці намагаються економити на робочій силі. 
Вирішення проблем зайнятості є одним із важливих аспектів підвищення добробуту сільського населення, який досяжний у тому числі шляхом підтримки соціально-економічної результативності господарювання підприємств. У більшості підприємців мотивація соціально-економічної поведінки щодо створення додаткових робочих місць зовсім інша. Підприємці природно прагнуть до економії на робочій силі, зокрема, для цього залучають організаційні, технологічні новації, змінюють структуру виробництва. Критерії досягнення соціально-економічної результативності господарювання сільськогосподарських підприємств залежать від загального розвитку економіки. Соціальний складник не на першому місці - бізнес мінімізує зайнятість, щоб оптимізувати витрати на робочу силу, що проявляється на загальнодержавному і на регіональному рівні.

Регіональні аспекти сільської зайнятості як важлива соціально-економічна проблема вирішується по-різному, але прямою є залежність цього питання від сільськогосподарських підприємців. Наприклад, у Вінницькій області, яка за економічною спеціалізацією $є$ аграрною, сільське господарство - головна сфера зайнятості населення. Інтеграція ефективності господарювання, за наслідками, у соціально-економічну результативність залежить від підприємницьких можливостей і мотивацій. У регіоні функціонують різні типи підприємств - за структурною моделлю зайнятості: 1) підприємства із застарілою технікою i технологіями - в них частково зберігся кількісний потенціал зайнятих; 2) підприємства інноваційнотехнологічні - потребують мешої чисельності працівників, але з високою кваліфікацією.

Проте в першому разі - діяльність неприваблива, а заробітна плата у працівників невисока. Тут також спостерігаються різнопланові характеристики соціально-економічної результативності підприємницького господарювання - 3 одного боку, підприємства 3 відносно великою чисельністю найманих працівників і невисокою зарп-

Таблиця 1 - Динаміка зайнятості населення за основними видами економічної діяльності в Україні*

\begin{tabular}{|c|c|c|c|c|c|c|c|c|c|c|}
\hline & \multicolumn{5}{|c|}{$\begin{array}{c}\text { Кількість зайнятого населення, } \\
\text { тис. осіб }\end{array}$} & \multicolumn{5}{|c|}{$\begin{array}{c}\text { Кількість найманих працівників, } \\
\text { тис. осіб }\end{array}$} \\
\hline & 2015 & 2016 & 2017 & 2018 & 2019 & 2015 & 2016 & 2017 & 2018 & 2019 \\
\hline Усього & 18073,3 & 16443,2 & 16276,9 & 16156,4 & 16360,9 & 6078,0 & 5778,1 & 5713,9 & 5714,6 & 5808,6 \\
\hline $\begin{array}{l}\text { Сільське, лісове та } \\
\text { рибне господарство }\end{array}$ & 3091,4 & 2870,6 & 2866,5 & 2860,7 & 2937,6 & 591,3 & 569,4 & 583,4 & 558,1 & 540,5 \\
\hline Промисловість & 2898,2 & 2573,9 & 2494,8 & 2440,6 & 2426,0 & 2363,0 & 2241,4 & 2168,4 & 2142,6 & 2092,0 \\
\hline \multirow[t]{2}{*}{ Будівництво } & 746,4 & 642,1 & 644,5 & 644,3 & 665,3 & 276,4 & 239,2 & 241,7 & 251,9 & 266,1 \\
\hline & \multicolumn{5}{|c|}{ \% до загального підсумку } & \multicolumn{5}{|c|}{ \% до загального підсумку } \\
\hline Усього & 100,0 & 100,0 & 100,0 & 100,0 & 100,0 & 100,0 & 100,0 & 100,0 & 100,0 & 100,0 \\
\hline $\begin{array}{l}\text { Сільське, лісове та } \\
\text { рибне господарство }\end{array}$ & 17,1 & 17,5 & 17,6 & 17,7 & 18,0 & 9,7 & 9,9 & 10,2 & 9,8 & 9,3 \\
\hline Промисловість & 16,1 & 15,7 & 15,3 & 15,1 & 14,8 & 38,9 & 38,8 & 38,0 & 37,5 & 36,0 \\
\hline Будівництво & 4,1 & 3,9 & 4,0 & 4,0 & 4,1 & 4,5 & 4,1 & 4,2 & 4,4 & 4,6 \\
\hline
\end{tabular}

* Взято галузі «створювальної» діяльності.

Джерело: Побудовано за даними Державної служби статистики Украӥни

Таблиця 2 - Динаміка співвідношення середньомісячної заробітної плати працівників «сільських» галузей з іншими видами економічної діяльності «створювального» характеру*

\begin{tabular}{|c|c|c|c|c|c|c|c|c|c|c|c|c|c|}
\hline \multirow{3}{*}{$\begin{array}{c}\text { Вид } \\
\text { економічної } \\
\text { діяльності }\end{array}$} & \multicolumn{5}{|c|}{$\begin{array}{c}\text { абсолютні показники рівня } \\
\text { середньомісячної номінальної } \\
\text { заробітної плати }\end{array}$} & \multicolumn{8}{|c|}{ зміни до попереднього року } \\
\hline & 2014 & 2015 & 2016 & 2017 & 2018 & 2015 & 2016 & 2017 & 2018 & 2015 & 2016 & 2017 & 2018 \\
\hline & \multicolumn{5}{|c|}{ Розмір, грн./міс } & \multicolumn{4}{|c|}{$\%$} & \multicolumn{4}{|c|}{,+- - 2pH./Mic } \\
\hline $\begin{array}{l}\text { Сільське, лісове та } \\
\text { рибне господарство }\end{array}$ & 2556 & 3309 & 4195 & 6057 & 7557 & 129,5 & 126,8 & 144,4 & 124,8 & 753 & 886 & 1862 & 1500 \\
\hline $\begin{array}{l}\text { Сільське } \\
\text { господарство }\end{array}$ & 2476 & 3140 & 3916 & 5761 & 7166 & 126,8 & 124,7 & 147,1 & 124,4 & 664 & 776 & 1845 & 1405 \\
\hline Промисловість & 3988 & 4789 & 5902 & 7631 & 9633 & 120,1 & 123,2 & 129,3 & 126,2 & 801 & 1113 & 1729 & 2002 \\
\hline Будівництво & 2860 & 3551 & 4731 & 6251 & 7845 & 124,2 & 133,2 & 132,1 & 125,5 & 691 & 1180 & 1520 & 1594 \\
\hline Усього & 3480 & 4195 & 5183 & 7104 & 8865 & 120,5 & 123,6 & 137,1 & 124,8 & 715 & 988 & 1921 & 1761 \\
\hline
\end{tabular}

Джерело: наведено і розраховано з даних Державної служби статистики України 
латою, а $з$ іншого - меншою чисельністю зайнятих із значно вищою оплатою праці. При цьому, наприклад, площа землі в користуванні може бути рівнозначною, але структура виробництва, спеціалізація різні.

Вважаємо, що на загальнодержавному і регіональному рівні соціально-економічна результативність підприємницького господарювання в частині зайнятості та мотивації не задовольняє потреби сільського розвитку. Адже сільськогосподарські товаровиробники першочергово турбуються про власний підприємницький прибуток, хоча в останні роки по галузі спостерігається значне підвищення заробітних плат (табл. 2). Одна 3 причин цього - нестача робочої сили, зокрема і кваліфікованої, через обезлюднення сіл і відтік працівників на роботи за кордон.

За оцінками вітчизняних аграрних економістів, які пропонують науково обгрунтовані Стратегічні напрями сталого розвитку сільських територій на період 2030 року [17], «оплата праці в аграрній сфері $є$ найнижчою серед галузей економіки, загострюються проблеми бідності, залишається низьким рівень життя людей. У 2018 р. майже 49\% домогосподарств у сільській місцевості мали середньодушові грошові доходи на місяць, які нижчі від фактичного прожиткового мінімуму. У структурі грошових доходів домогосподарств у сільській місцевості частка оплати праці становить $49,5 \%$, тоді як більша частина сімейного бюджету $(53,6 \%)$ у домогосподарствах селян витрачається на продовольчі товари. Фактичний рівень душового споживання харчових продуктів порівняно 3 науково обгрунтованими нормами становить у середньому 63\%» [17, с. 10$]$.
Незважаючи на деякі покращення в останню п’ятирічку, коли завдяки сприятливій економічній кон'юнктурі ринків сільськогосподарської продукції та продовольства виробники мали можливість покращувати матеріально-стимулятивні умови зайнятості персоналу - підвищуючи рівень заробітної плати (див. табл. 2), проблеми соціально-економічного розвитку села залишаються здебільшого невирішеними.

Відповідно аналіз ситуації, соціально-економічної результативності підприємницького господарювання на селі характеризує аспект соціальної відповідальності, про що можна судити, аналізуючи динаміку зайнятості. Оцінкою цієї ситуації характеризується те, наскільки сільські підприємці є соціально відповідальними в плані створення робочих місць, підвищення заробітної плати персоналу. Загалом сучасне функціонування сільськогосподарських підприємств відповідає капіталістичному способу виробництва. Відзначимо, що, наприклад, соціально спрямовані витрати, які вважаємо індикатором соціальної відповідальності сільськогосподарського підприємства у виробничій системі, здійснюються за залишковим принципом.

Безпосередньо оцінка динаміки соціально спрямованих витрат у виробничій системі сільськогосподарських підприємств, тобто витрат на оплату праці (рис. 2) вказує на зниження рівня соціально-економічної результативності господарювання за критерієм стимулювання зайнятості.

3 аналітичних характеристик соціальної відповідальності припускаємо, що на селі проблема працевлаштування стоїть гостро, адже значна частина населення живе із зайнятості в особис-

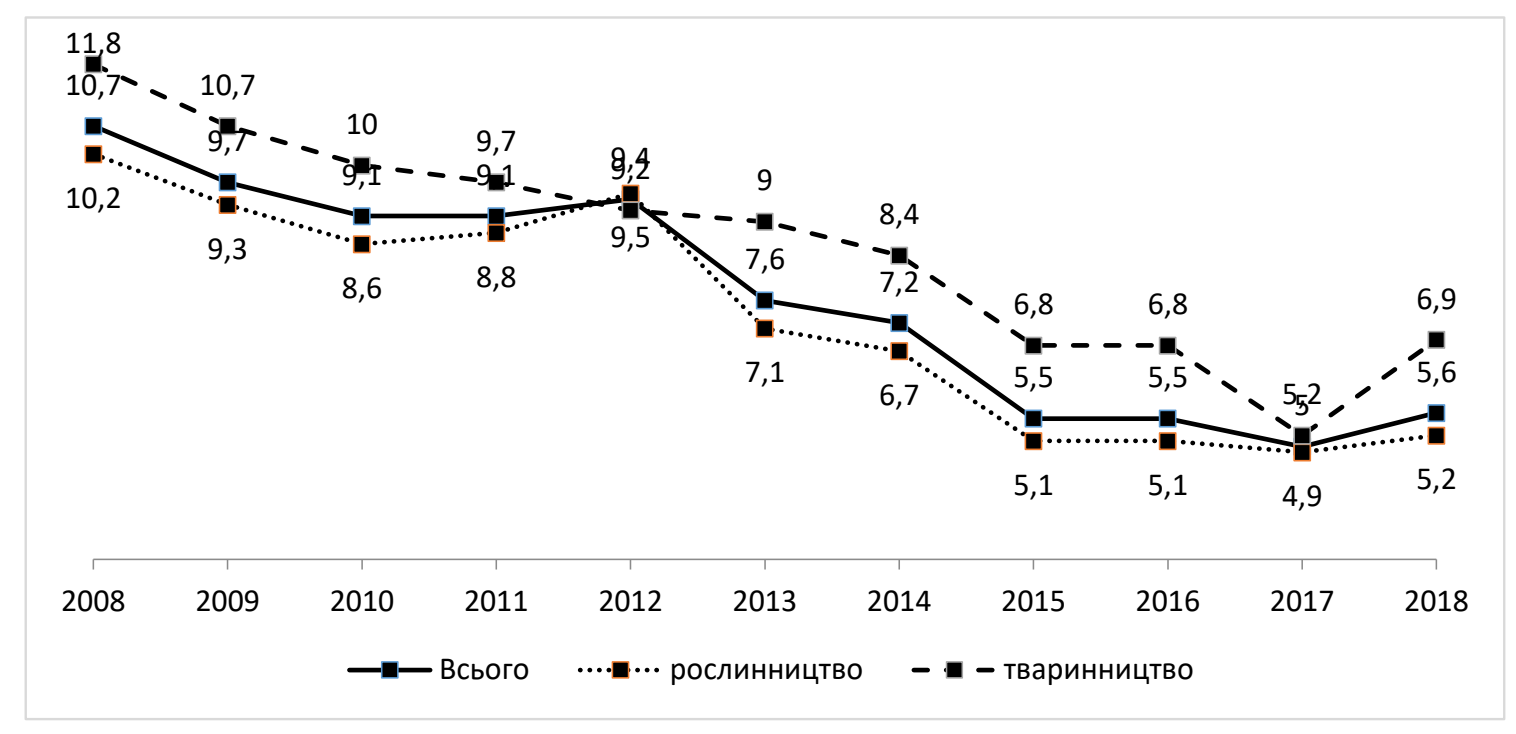

Рисунок 2 - Динаміка частки оплати праці у витратах виробництва сільськогосподарських підприємств України*

Джерело: побудовано за даними Державної служби статистики Украӥни 
тому секторі. За рахунок продажу продукції з цих господарств селяни забезпечують певний рівень життя для себе і своєї сім'ї, проте прагнення мати оплачувану роботу нікуди не зникло, особливо характерне воно для осіб працездатного віку.

Однак для більшості жителів села, зокрема молодих людей, які закінчили заклади вищої освіти, перспектива знайти достойну роботу досить складна, і це не тільки в сільськогосподарських структурах, а також в інших підприємствах. У зв'язку з цим пріоритет зайнятості для молоді - несільськогосподарські сектори, які здебільшого на селі відсутні. Разюча різниця в умовах життя на селі, заробітках є результатом неспроможності, а подекуди - небажання сільських господарюючих суб'єктів формувати достойні умови праці, зокрема за оплатою - факт низької їх соціально-економічної результативності. Підприємницькі формування розвивають капіталістичну модель діяльності, адже соціальний складник - на другому плані.

Сьогодні ситуація із забезпеченням зайнятості населення в сільськогосподарському підприємництві, зокрема соціально відповідальна діяльність зі створення додаткових робочих місць - перебуває у прямій залежності від кон'юнктури агропродовольчого ринку. Спостерігаємо деяку стабільність чисельності зайнятих у сільському господарстві. Відповідно можемо зазначити, що сільськогосподарські підприємці - наймачі персоналу - задовольняють свої кон'юнктурні позиції на ринку наявним рівнем соціальної відповідальності щодо створення умов для зайнятості населення.

Висновки. Виключна соціальна значущість сільськогосподарського підприємництва є беззаперечною, але 3 огляду на ситуацію, яка склалася нині, ці підприємства акумулюють і використовують наявні в них матеріально-фінансові ресурси на вирішення виробничих завдань. Власники сільськогосподарських підприємств переважно усунулися від вирішення соціальних проблем, не виконують селозберігаючих функцій - як за часів колгоспно-радгоспної системи. У мотиваціях господарювання переважає бажання з максимального нагромадження капіталу, лише поодинокі підприємці, переважного середнього і нижче середнього масштабу (малі) дбають про добробут сільської громади, бо живуть та працюють на селі. Більшість соціальну діяльність здійснюють фрагментарно. Підсумовуючи наведений матеріал, зазначимо, що функціонування вітчизняного аграрного комплексу оцінюється переважно за вартісними показниками, через низку причин соціальний вимір забезпечення розвитку, зокрема результати і тенденції, які відбулися в галузі за наслідком ефективності господарювання (соціальний блок питань), відійшли на другий план. Соціальний складник не отримує належної уваги в регуляторній політиці держави, оцінках економічної динаміки розвитку села, навіть у наукових публікаціях, тому проблема залишиться перспективною і для подальших досліджень.

\section{Список використаних джерел:}

1. Соціологічна енциклопедія / Укладач В.Г. Городяненко. К. : Академвидав. 2008. 456 с. (Серія «Енциклопедія ерудита»)

2. Формування об’єднаних територіальних громад у сільській місцевості (інформаційно-аналітичний огляд) / [Ю.О. Лупенко, М.Й. Малік, О.Г. Булавка та ін.]. Київ. : ННЦ «ІАЕ». 2020. 60 с.

3. Соціально-економічне становище сільських територій України (1990-2014 роки) : кол. монографія [у 2-х т.]. Т. 1. / [І.М. Демчак, Ю.О. Лупенко, М.К. Орлатий та ін.] Київ : НАДУ. 2016. 440 с.

4. Соціально-економічне становище сільських територій України (1990-2014 роки) : кол. монографія [у 2-х т.]. Т. 2. / [І.М. Демчак, Ю.О. Лупенко, М.К. Орлатий та ін.] Київ : НАДУ. 2016. 440 с.

5. Державна служба статистики України. URL: http://www.ukrstat.gov.ua/operativ/menu/ menu_u/zed.htm (дата звернення 20.03.2020).

6. Андрійчук В.Г. Ефективність діяльності аграрних підприємств: теорія, методика, аналіз: монографія. Київ: КНЕУ. 2005. 292 с.

7. Андрійчук В.Г., Сас І.С. Концентрація в аграрній сфері економіки: проблемні аспекти : монографія. Київ. 2017. 303 с.

8. Науково-практичні рекомендації з обгрунтування методичних підходів щодо ефективної реструктуризації аграрної галузі в умовах сталого розвитку сільських територій / А.П. Сава, М.Г. Саєнко, О.Р. Олійник та ін. Тернопіль. 2015. $80 \mathrm{c}$.

9. Національна парадигма сталого розвитку України / за заг. ред. акад. НАН України, д.т.н., проф., заслуженого діяча науки і техніки України Б.С. Патона. Вид. 2-ге, переробл. і доповн. Київ. Державна установа «Інститут економіки природокористування та сталого розвитку Національної академії наук України». 2016. 72 с.

10. Данько Ю.І. Формування систем забезпечення конкурентоспроможності аграрних підприємств: монографія. Суми : університетська книга. 2016. 301 с.

11. Підприємництво в епоху глобальних трансформацій: виклики та перспективи розвитку : монографія / [Пашко П. В., Лазебник Л. Л., Кіндзерський Ю. В. та ін.] ; за ред. д.е.н., професора П. В. Пашка та д.е.н., професора Л. Л. Лазебник ; Університет державної фіскальної служби України. Ірпінь, 2019. 476 с. URL: http://ir.nusta.edu.ua/jspui/bitstream/ doc/4140/1/2961_IR.pdf (дата звернення: 07.04.2020).

12. Перспективні форми організації господарської діяльності на селі: наук. доп. / Ю. О. Лупенко та ін. Київ : ННЦ «IAE», 2019. 114 c.

13. Розвиток підприємництва і кооперації: інституціональний аспект : моногр. / [Лупенко Ю.О., Малік М.Й., Заяць В.М. та інші]. Київ, 2016. 430 с. 
14. Шпикуляк О.Г., Малік М.Й. Інституціональний аналіз розвитку підприємництва в аграрному секторі економіки: методичний аспект. Економіка АПК. 2019. №6. С. 73-82.

15. Горін Н. О. Соціально-технологічна парадигма підприємництва. Український соціум. 2015. № 3 (54). С. 86-95. URL: https://ukr-socium.org.ua/wp-content/uploads/2015/07/86-95_no-3_vol-54_2015_UKR.pdf (дата звернення: 07.04.2020).

16. Соціально-економічний потенціал сталого розвитку України та ії регіонів: національна доповідь / за ред. акад. НАН України Е.М. Лібанової, акад. НААН України М.А. Хвесика. Київ. ДУ ІЕПСР НАН України, 2014. 776 с.

17. Стратегічні напрями сталого розвитку сільських територій на період до 2030 року / [Лупенко Ю.О., Малік М.Й., Булавка О.Г. та ін.]; за ред. Ю.О. Лупенка. Київ.: ННЦ ІАЕ, 2020. 60 с.

18. Варналій 3.С. Конкуренція і підприємництво : моногр. Київ. : Знання України, 2015. 463 с.

\section{References:}

1. Sociological encyclopedia [Sociological encyclopedia] (2008) / Compiled V.H. Horodyanenko. Kyiv : Akademvydav (Series "Encyclopedia erudite") (In Ukrainian).

2. Formuvannia obiednanykh terytorialnykh hromad u silskii mistsevosti (informatsiino-analitychnyi ohliad) [2. Formation of integrated territorial communities in rural areas (informational-analytical review)] (2020) / [Iu.O. Lupenko, M.I. Malik, O.H. Bulavka ta in.]. Kyiv. : NNTs «IAE». 60 p. (In Ukrainian).

3. Sotsialno-ekonomichne stanovyshche silskykh terytorii Ukrainy (1990-2014 roky) [Socio-economic situation of rural territories of Ukraine (1990-2014)]: kol. monohrafiia [u 2-kh t.]. T1. / [I.M. Demchak, Yu.O. Lupenko, M.K. Orlatyi ta in.] Kyiv : NADU. 2016. 440 p. (In Ukrainian).

4. Sotsialno-ekonomichne stanovyshche silskykh terytorii Ukrainy (1990-2014 roky) [Socio-economic situation of rural territories of Ukraine (1990-2014)]: kol. monohrafiia [u 2-kh t.]. T2. / [I.M. Demchak, Yu.O. Lupenko, M.K. Orlatyi ta in.] Kyiv : NADU. 2016. 440 p. (In Ukrainian).

5. The official site of the State Statistics Service of Ukraine, available at URL: http://www.ukrstat.gov.ua/operativ/menu/ menu_u/zed.htm (Accessed 20 March 2020).

6. Andriichuk V.H. Efektyvnist diialnosti ahrarnykh pidpryiemstv: teoriia, metodyka, analiz [The effectiveness of agricultural enterprises: theory, methodology, analysis]: monohrafiia. Kyiv: KNEU. 2005. 292 p. (in Ukrainian).

7. Andriichuk V.H., Sas I.S. Kontsentratsiia v ahrarnii sferi ekonomiky: problemni aspekty : monohrafiia [Concentration in the agricultural sphere of the economy: problematic aspects]. Kyiv. 2017. 303 p. (in Ukrainian).

8. Naukovo-praktychni rekomendatsii z obgruntuvannia metodychnykh pidkhodiv shchodo efektyvnoi restrukturyzatsii ahrarnoi haluzi v umovakh staloho rozvytku silskykh terytorii [Scientific and practical recommendations for substantiation of methodological approaches to the effective restructuring of the agricultural sector in the conditions of sustainable development of rural areas] / A.P. Sava, M.H. Saienko, O.R. Oliinyk ta in. Ternopil. 2015. 80 p. (in Ukrainian).

9. Natsionalna paradyhma staloho rozvytku Ukrainy [National paradigm of sustainable development of Ukraine] / za zah. red. akad. NAN Ukrainy, d.t.n., prof., zasluzhenoho diiacha nauky i tekhniky Ukrainy B.Ie. Patona. Vyd. 2-he, pererobl. i dopovn. Kyiv. Derzhavna ustanova «Instytut ekonomiky pryrodokorystuvannia ta staloho rozvytku Natsionalnoi akademii nauk Ukrainy». 2016. 72 p. (in Ukrainian).

10. Danko Yu.I. Formuvannia system zabezpechennia konkurentospromozhnosti ahrarnykh pidpryiemstv [Formation of systems for ensuring the competitiveness of agricultural enterprises]: monohrafiia. Sumy : universytetska knyha. $2016.301 \mathrm{p}$. (in Ukrainian).

11. Pidpryiemnytstvo v epokhu hlobalnykh transformatsii: vyklyky ta perspektyvy rozvytku [Entrepreneurship in the age o f global transformation: challenges and prospects] : monohrafiia / [Pashko P. V., Lazebnyk L. L., Kindzerskyi Yu. V. ta in.] ; za red. d.e.n., profesora P. V. Pashka ta d.e.n., profesora L. L. Lazebnyk ; Universytet derzhavnoi fiskalnoi sluzhby Ukrainy. Irpin, 2019. 476 p. URL: http://ir.nusta.edu.ua/jspui/bitstream/doc/4140/1/2961_IR.pdf (Accessed 7 April 2020).

12. Perspektyvni formy orhanizatsii hospodarskoi diialnosti na seli [Perspective forms of organization of economic activity in the countryside]: nauk. dop. (2019) / Yu.O. Lupenko ta in. Kyiv : NNTs «IAE». 114 p. (in Ukrainian)

13. Rozvytok pidpryiemnytstva i kooperatsii: instytutsionalnyi aspekt [13. Development of entrepreneurship and cooperation: institutional aspect]: monohr. / [Lupenko Yu.O., Malik M.I., Zaiats V.M. ta inshi]. Kyiv, 2016. 430 p. (in Ukrainian)

14. Shpykuliak O.H., Malik M.I. Instytutsionalnyi analiz rozvytku pidpryiemnytstva v ahrarnomu sektori ekonomiky: metodychnyi aspekt. [nstitutional analysis of entrepreneurship development in agricultural sector of economy: methodical aspect]. Ekonomika APK. 2019. vol 6. pp. 73-82. (in Ukrainian)

15. Horin N. O. Sotsialno-tekhnolohichna paradyhma pidpryiemnytstva [Socio-technological paradigm of entrepreneurship]. Ukrainskyi sotsium. 2015. vol. 3 (54). pp. 86-95. URL: https://ukr-socium.org.ua/wp-content/uploads/2015/07/ 86-95_no-3_vol-54_2015_UKR.pdf (Accessed 7 April 2020).

16. Sotsialno-ekonomichnyi potentsial staloho rozvytku Ukrainy ta yii rehioniv [Socio-economic potential of sustainable development of Ukraine and its regions]: natsionalna dopovid / za red. akad. NAN Ukrainy E.M. Libanovoi, akad. NAAN Ukrainy M.A. Khvesyka. Kyiv. DU IEPSR NAN Ukrainy, 2014. 776 p. (in Ukrainian).

17. Stratehichni napriamy staloho rozvytku silskykh terytorii na period do 2030 roku [Strategic directions for sustainable rural development for the period up to 2030] / [Lupenko Yu.O., Malik M.I., Bulavka O.H. ta in.]; za red. Yu.O. Lupenka. Kyiv.: NNTs IAE, 2020. 60 p. (in Ukrainian).

18. Varnalii Z.S. (2015). Konkurentsiia i pidpryiemnytstvo [Competition and entrepreneurship]: monohr. Kyiv. : Znannia Ukrainy. 463 p. (in Ukrainian). 
Diuk Anna

Vinnytsia National Agrarian University

\section{SOCIO-ECONOMIC RESULTS OF ENTREPRENEURIAL ECONOMY IN RURAL DEVELOPMENT: THE EMPLOYMENT ASPECT}

The article makes theoretical and practical assessments of socio-economic performance of entrepreneurship in rural development regarding modern aspects of population employment and work motivation. The principles of the importance of rural entrepreneurship as a mechanism for promoting the development of rural territories - a factor on which they fundamentally depend - are substantiated. The methodological set of evaluation sectors in which it is proposed to fix the methodological set of indicators for analyzing the results of activities of enterprises having socioeconomic connection with rural development is determined.

Conceptually proposed indicators of socio-economic performance of business management. The systematic connection of rural business performance with demographic, social, economic and environmental problems is outlined.

The dynamics of employment and remuneration by main types of economic activity in Ukraine, based on the results of business management and industry characteristics of doing business, is analyzed.

Conceptually identified types of enterprises by level of innovation as a base for job creation. The dynamics of the sectoral wage ratio and its change in the context of assessing the socio-economic performance of the economy are determined. The connection of social responsibility of agricultural entrepreneurship with rural development has been methodically proved. Prospects of research of the problem in the context of development of a village-saving model of economy are offered.

The exceptional social importance of agricultural entrepreneurship is indisputable, but given the current situation, these enterprises accumulate and use the material and financial resources available to them to solve production problems. The owners of agricultural enterprises have mostly escaped from solving social problems and do not perform village-preserving functions - as in the times of the collective-farm system. In the motivations of management, the desire to maximize capital accumulation prevails, only a few entrepreneurs, mostly middle and lower middle (small), care about the well-being of the rural community because they live and work in the countryside.

Key words: entrepreneurship, management, socio-economic performance, employment, labor motivation.

JEL classification: I38. 